УДК 631.4/18:631.48:631.18

(C) 2015

Крамарьов С. М., доктор сільськогосподарських наук, Крамарьов О. С., матістр

ДУ Інститут сільського господарства степової зони НААН України

Христенко А. О., кандидат сільськогосподарських наук

ННЦ Інститут грунтознавста і агрохімії ім. О. Н. Соколовського НААН України

Токмакова Л. М., кандидат сільськогосподарських наук

ДУ Інститут сільськогосподарської мікробіології та агропромислового виробництва НААН України

Жученко С. І., кандидат сільськогосподарських наук,

Сироватко В. А., кандидат біологічних наук,

Цьова Ю. А., аспірант

(науковий керівник - доктор сільськогосподарських наук, професор П. В. Писаренко)

Полтавська державна аграрна академія

Сироватко К. В., інженер

Дніпропетровська філія ДУ Інституту охорони грунтів

\title{
ЗМIНА ВМІСТУ РУХОМОГО ФОСФОРУ В ГЕНЕТИЧНИХ ГОРИЗОНТАХ ЧОРНОЗЕМУ ЗВИЧАЙНОГО
}

Рецензент - доктор сільськогосподарських наук, професор П. В. Писаренко

Чорноземи звичайні на лесових породах важкого транулометричного складу Північного Степу України містять підвищену кількість апатитоподібних сполук. Внаслідок изього використання будь-яких кислотних методів, у тому числі ГОСТ 26204-91 (метод Чирикова) призводить до істотного итучного завищення оцінки фосфатного стану трунтів (на 40-80 мг $\mathrm{P}_{2} \mathrm{O}_{5} /$ к трунту ). Для діагностики фосфатного стану даних трунтів, згідно з вимогами нормативних документів України, слід використовувати наступні стандарти: ДСТУ 4114 (метод Мачігина), ДСТУ 4727 (метод Карпінського-Зам'ятіної) $і$ ДСТУ ISO 11263 (метод Olsen). Для отримання високих урожаїв із високою якістю на чорноземах звичайних Північного Степу України необхідно вносити не менше фосфорних добрив, ніж на інших трунтах краӥни виходячи з даних трунтової діагностики.

Ключові слова: вміст рухомого фосфору, чорнозем звичайний, сільськогосподарська продукиія, поживний режим.

Постановка проблеми. Поряд з азотом, другим за важливістю елементом мінерального живлення, який в більшості випадків лімітує подальший ріст врожайності зерна всіх без виключення сільськогосподарських культур, $є$ фосфор [3]. «Про це повинен пам'ятати кожен хлібороб», неодноразово наголошував у своїх наукових працях академік В. Д. Панніков (В. Д. Панніков, 2003). Адже від рівня його засвоєння та метаболізму залежать визначально важливі етапи онто- генезу рослин та формування продуктивності агроценозів майже всіх зернових культур.

Заради справедливості слід відмітити, що на основі багаторічних польових, а також вегетаційних дослідів, Д. М. Прянішніков ще в 1924 році створив першу грунтово-агрохімічну карту колишнього СРСР, на якій він відносив Чорноземну зону, в тому числі і наші степові грунти до районів, які терміново потребують внесення фосфорних добрив. Він писав, що в чорноземах $\epsilon$ «великий запас азоту, поки що вистачає калію: потрібно добавити лише один елемент - фосфор, щоб відновити чорнозем, виснажений тривалою культурою без добрив, яка розпочалася 3 часів хрещення Русі, або й ще раніше» (Д. М. Прянішніков, 1924).

Це пов'язано з тим, що в більшості типів грунтів фосфор знаходиться в слаборозчинній мінеральній та недоступній рослинам органічній формах, а майже всі сільськогосподарські культури, лише за виключенням тих їх видів (гречка, люпин, горох та інші), у яких співвідношення $\mathrm{CaO} / \mathrm{P}_{2} \mathrm{O}_{5}$ більше 1,3 , здатні поглинати $\mathrm{P}_{2} \mathrm{O}_{5}$ iз $\mathrm{Ca}_{3}\left(\mathrm{PO}_{4}\right)_{2}$, розчиняючи фосфати своїми ексудатами або вивільняючи фосфор за рахунок інтенсивного поглинання з грунтового розчину катіонів кальцію, а ярі та озимі зернові колосові культури поглинають лише рухому його форму, оскільки вищеназване співвідношення значно менше цього показника (Чириков, 1950). Ярі та 


\section{СІЛЬСЬКЕ ГОСПОДАРСТВО. РОСЛИННИЦТВО}

озимі зернові культури (пшениця, жито, тритикале, ячмінь, кукурудза) слабо засвоюють важкорозчинні сполуки фосфору з грунту, тому вони добре реагують на внесення легкорозчинних форм фосфорних добрив, оскільки енергійно вбирають фосфор і менше кальцій. За таких умов наявний надлишок катіонів кальцію хімічно зв'язує рухомий фосфор в слаборозчинні фосфати [3]. Тому в умовах Степу серед елементів живлення, що знаходяться в дефіциті, на першому місці стоїть фосфор, а потім вже азот, цинк і т. д. [4]. Частка фосфорних добрив у прирості врожаю зернових культур в цій зоні висока і становить 30-60, азотних значно менше - 15-40 і для калійних становить лише 0-20\%. Серед усіх форм фосфору найбільший вплив на врожай має рухома форма. Безумовно, особливо важлива роль рухомих форм фосфору проявляється на початку росту та розвитку рослин і особливо сильно відчувається на стадії проростків, тому його обов'язково вносять у грунт завчасно (Лихочвор В. В., 2008). Старші ж рослини слабше реагують на нестачу цього елемента живлення. Цей елемент зменшує негативну дію надлишкового азотного удобрення, оптимізує використання мінерального азоту й підвищує ефективність азотних добрив.

Проте поряд 3 цим, оптимальне забезпечення грунту рухомими формами цього елемента живлення $є$ також важливим і впродовж усього онтогенезу. Однак в більшості типів грунтів рухомі форми цього важливого елемента мінерального живлення рослин знаходиться в мінімумі і стримують подальшій ріст продуктивності сільськогосподарських культур [8]. Тут доречним буде відмітити, що в Україні площа ріллі з низьким і середнім умістом рухомого фосфору досягає 17812 гектарів, або $57 \%$ загальної площі (Металіді, 1999; Носко, 1997). Саме через низьку забезпеченість грунтів доступним для рослин фосфором окупність фосфорних добрив досить висока - у середньому 1 кг $\mathrm{P}_{2} \mathrm{O}_{5}$ забезпечуе приріст 4-5 кг зерна. Внаслідок зниження вмісту фосфору в грунті вже у найближчі роки в Україні зменшення продуктивності сівозмін сягне 2,2 зернової одиниці (Медведєв, 2000).

Парадокс проблеми фосфорного живлення рослин полягає в тому, що валові запаси фосфору в більшості грунтів в основному значні, однак на $40 \%$ площ орних земель світу продуктивність зернових культур лімітується нестачею рухомих форм фосфору (Гуляєв, 2004; Нікітішен, 2002; Ma, 2000; Rengel, 2005). Це пояснюється тим, що в складі валових запасів фосфору в метровому шарі грунтів домінуюче положення займають слаборозчинні форми, а вміст рухомих форм, навпаки, незначний і не завжди відповідає потребам рослин (Носко, 1990). Тому ефективна родючість більшості грунтів в основному обмежується недостатньою забезпеченістю їх рухомими формами фосфору [10].

Крім того, на відміну від інших елементів органічної речовини грунту $(\mathrm{C}, \mathrm{H}, \mathrm{O}, \mathrm{N})$, які надходять у грунт переважно із атмосфери, основним первинним джерелом фосфору $є$ грунтоутворююча материнська порода (Маккелві, 1977), яка не завжди в змозі забезпечити в достатній кількості грунтовий розчин рухомими формами фосфору. Це також пов'язано ще й 3 тим, що фосфор за своїми хімічними властивостями має складну природу взаємодії з компонентами грунту.

Ця обставина значною мірою ускладнює отримання об'єктивної оцінки забезпеченості грунту цим елементом мінерального живлення рослин. Тому для уникнення його дефіциту, дуже важливим є своєчасне отримання інформації про вміст у грунті рухомих форм фосфору і підтримування оптимального рівня доступного для рослин його форм упродовж усього онтогенезу, внесенням фосфоровмісних добрив [3]. Точне визначення показників рухомих сполук фосфору в грунті дає змогу ефективніше використовувати природні ресурси та прогнозувати ефективність фосфорних добрив [11]. Недостовірна інформація про фосфатний стан грунтів, навпаки, призводить до вкрай неефективного використання добрив [17].

Аналіз останніх досліджень і публікацій, у яких започатковано розв'язання проблеми. Застосування методів визначення вмісту фосфору без урахування конкретних особливостей грунтів, а також недостатнє відпрацювання методичних аспектів діагностики живлення рослин призводить до викривлення оцінки стану родючості грунтів цілих регіонів $[2,18]$. Це пов'язано 3 тим, що більшість методів базується на використанні в якості екстрагентів розчинів сильних кислот, що свідчить про їх належність до так званих жорстких методів (Стахів, 2007; Христенко, 2003, 2008). Використання цих методів на досить кислих грунтах призводить до істотного заниження даних за рахунок сильного повторного поглинання $\mathrm{P}_{2} \mathrm{O}_{5}$ під час проведення аналізу, а в грунтах, що мають підвищений уміст апатитоподібних сполук, навпаки, до істотного їх завищення. Навіть вкрай слабка лужність грунтів викликає часткову нейтралізацію кислоти і знову ж заниження результатів, які отримують (Носко, 1999). Головним критерієм під час вибору мето- 


\section{СІЛЬСЬКЕ ГОСПОДАРСТВО. РОСЛИННИЦТВО}

ду для вилучення рухомих сполук фосфору 3 грунту $є$ оцінка його здатності правильно відображати реакцію рослин на внесення фосфорних добрив [14].

3 вищевикладеного стає зрозумілим, що рухомий (доступний) фосфор, відіграє особливо важливе значення в мінеральному живленні рослин і методично правильне визначення його вмісту в грунтовому розчині має надзвичайно важливе значення під час проведення розрахунків оптимальних доз внесення фосфорних добрив. Тому його завжди не вистачає в грунтовому розчині, оскільки він становить незначний відсоток від наявних у грунті його валових форм [6].

Щоб чітко уявити собі це, потрібно провести порівняння вмісту в грунті валових і рухомих форм фосфору. Проведене співставлення показало, що в чорноземах звичайних вміст валових форм фосфору $(0,11-0,12 \%)$ становить 1100 1200 мг/кг грунту. Вміст же рухомих його форм, визначених за методом Чирикова, які переходять у слабокислотні витяжки $0,5 \mathrm{~N}$ оцтової кислоти й частково беруть безпосередню участь у фосфатному живленні рослин (98-167 мг/кг грунту), містяться в грунті в незначній кількості й становлять усього лише 8,2-13,9\% від валового вмісту фосфору. Тому рухомі форми фосфору перебувають у першому мінімуму серед інших макроелементів в даних грунтах [15-17].

У наукові літературі [11-15] поряд з терміном рухомий для виділення з усієї сукупності фосфоровмісних мінеральних сполук доступні для рослин форми часто використовують й інші терміни, які є синонімами - «засвоюваний, лабільний» фосфор. Однак нечіткість цієї низки термінів заважає одержувати об'єктивну оцінку поживного режиму конкретного грунту. Поняття «рухомий» фосфор, калій та інші помилково асоціюється 3 концентрацією конкретного елементу живлення рослин у грунтовому розчині, залежною від властивостей грунтів та інших чинників [13, 14]. Рухомість - це скоріше міра доступності елементу рослинам. Вміст рухомих форм поживних речовин в екстенсивно використовуваній ріллі - величина постійна для кожного з елементів [16]. Значення даних констант визначається фізико-хімічними умовами, характерними для поверхні планети. Ілюзія різної природної забезпеченості різних типів орних грунтів і строкатості конкретного поля відносно рухомих форм елементів живлення рослин зумовлена недосконалістю нормативних і методичних аспектів діагностики живлення рослин (Христенко, 2009).
Відповідно до класичного визначення Д. М. Прянішнікова (1935) «засвоюваний фосфор не $є$ певною хімічною сполукою й не перебуває в готовому вигляді в грунті». У тім про те, що не все так просто, свідчить назва єдиного міжнародного стандарту, що встановлює метод визначення рухомого фосфору в грунтах - ISO 11236 (спектрометричний метод визначення фосфору в розчині гідрокарбонату натрію). В ньому акцент зроблено не на те, що визначаємо, а як визначаємо й за допомогою чого (Христенко, 2008).

Слід відмітити, що через безперервний процес поглинання цього поживного елемента рослинами, концентрація доступного фосфору завжди низька (Holford, 1997). Як відомо, рослини здатні поглинати фосфор із грунтового розчину навіть у випадку невеликих його концентраціях, таких як 0,01-0,02 мг/л $\mathrm{P}_{2} \mathrm{O}_{5}$ (Соколов А. В., 1950). До того ж у чорноземах звичайних вміст розчинних у воді фосфатів може відновлюватись за вегетаційний період більш ніж 100 разів (Носко Б. С., 2004). У зв'язку з цим для нормального росту $\mathrm{i}$ розвитку рослин важливою $є$ не стільки висока його концентрація в грунтовому розчині, як здатність грунту поповнювати запаси рухомого фосфору i таким чином ліквідувати його дефіцит, що й спостерігається в польових умовах під час мінерального живлення рослин $[8,9,11]$.

У даному випадку доступність фосфору в грунті для рослин залежить від його мобілізації та іммобілізації, які пов'язані з процесами розчинення чи осадження, сорбції і десорбції, мінералізації та біологічного закріплення його сполук (Антіпіна, 1991). Основним джерелом поповнення грунтового розчину рухомими формами фосфору є валові його запаси, які зосереджені в материнській породі та в фосфоровмісних органічних сполуках грунту [9]. Але поряд 3 ними суттєву роль відіграють і водорозчинні сполуки фосфору, які надходять у грунт з мінеральними добривами [14].

Як уже відмічалося вище, в грунті валові запаси фосфору відносно високі. Так, в орному шарі чорноземів звичайних вміст валових форм фосфору становить $0,11-0,12 \%$, а його валові запаси порівняно з азотом та калієм невеликі та варіюють у межах 5,4-5,5 т/га, а в метровому - 17,518,0 т/га (Б. С. Носко, 2004), що значно нижче, ніж вміст у цих грунтах валових форм калію. Основна кількість валового фосфору міститься у верхньому (0-25 см) шарі грунту, що пов'язано 3 діяльністю рослин, активним поглинанням його грунтом і внесенням добрив. Унаслідок процесів біологічного переносу в гумусовому горизонті 


\section{СІЛЬСЬКЕ ГОСПОДАРСТВО. РОСЛИННИЦТВО}

кількість його завжди більша, ніж у нижче розташованих та материнській породі. Валові запаси, як уже про це велась розмова вище, представлені органічними і мінеральними формами [7].

Органічні фосфати (нуклеїнові кислоти, фосфатиди, цукрофосфати та інше), частка яких становить 10-50 \% від загального вмісту фосфору, недоступні для рослин і беруть участь у живленні тільки після їх гідролізу і відокремлення фосфору [8]. Тобто головним чином фосфорорганічні сполуки грунту засвоюються рослинами лише після їх мінералізації. Але частка вивільненого мікроорганізмами органічного фосфору, який бере безпосередню участь у мінеральному живленні рослин незначна [6]. Це пов'язано 3 тим, що під час мікробіологічного розкладання фосфатовмісних органічних сполук, фосфор частково зв'язується мікрофлорою грунту, а потім, після розмноження цих мікроорганізмів, цей пул фосфору знову переходить до нових їх колоній. I лише чотири його відсотки із загальної кількості звільняється і переходить в мінеральну форму після їх відмирання (В. В. Швартау, В. І. Гуляєв, 2009). Тому основну роль в мінеральному живленні рослин займають мінеральні форми фосфору [11].

В чорноземах звичайних вміст мінеральних форм фосфору переважає над органічними [6]. Тому основну роль у фосфорному живленні рослин відіграють мінеральні форми фосфору [4]. К. С. Гінзбург (1981) відмічає, що в грунтах виявлено наявність 205 фосфоровмісних мінералів, які всі є солями ортофосфорної кислоти. В основному мінеральні сполуки фосфору представлені дуже багатьма формами, які є переважно важкорозчинними, в основному малорухливими формами і слабо доступними рослинам фосфатами [8]. Мінеральні фосфати у грунті складаються 3 багатьох солей, які утворилися $з$ ортофосфорної кислоти і є різними за хімічним складом та ступенем доступності для рослин [9].

Фосфор входить до складу мінералів: фторапатиту $\mathrm{Ca}_{5} \mathrm{~F}\left(\mathrm{PO}_{4}\right)_{3}$, гідроксил апатиту $\mathrm{Ca}_{3}\left(\mathrm{PO}_{4}\right)_{2} \cdot \mathrm{Ca}(\mathrm{OH})_{2}$, тавівіаніту $\mathrm{Fe}_{3}\left(\mathrm{PO}_{4}\right)_{2} \cdot 8 \mathrm{H}_{2} \mathrm{O}$ [9]. Серед них домінуюче положення займають різновидності мінералу апатиту, головним чином, фторапатитом. У лесовій материнській породі чорноземів звичайних фосфор міститься у вигляді фторапатиту $\mathrm{Ca}_{5}\left(\mathrm{~F}\left(\mathrm{PO}_{4}\right)_{3}\right.$ і кальцій гідроксилапатиту $\mathrm{Ca}_{5}(\mathrm{OH})\left(\mathrm{PO}_{4}\right)_{3}[14]$. У процесі руйнування цих первинних фосфоровмісних мінералів утворюються вторинні мінеральні сполуки фосфору, які містять у своєму складі різні солі ортофосфорної кислоти (А. В. Соколов, 1950). Мі- неральні форми фосфору в грунті представлені солями ортофосфорної кислоти, в яких фосфатний аніон хімічно зв'язаний 3 катіонами $\mathrm{Ca}^{2+}$, $\mathrm{Mg}^{2+}, \mathrm{Fe}^{2+}, \mathrm{Al}^{3+}, \mathrm{Mn}^{2+}$ та інші, значна частина яких знаходиться в поглинутому стані на поверхні грунтових колоїдів [10]. Характерною особливістю фосфатних грунтових сполук $є$ низька їх розчинність і слабка дисоціація на іони [4].

Фосфатні іони добре фіксуються твердою фазою грунту і їх міграція в чорноземах звичайних дуже обмежена [12]. Інтенсивне хімічне поглинання характерне для солей ортофосфорної кислоти, обумовлює слабку рухомість сполук фосфору. Швидкість їх дифузії в грунті незначна i варіює в межах від $10^{-12}$ до $10^{-15} \mathrm{~m}^{2} /$ сек., що уповільнює засвоєння фосфору рослинами, внаслідок чого прикоренева зона рослин швидко виснажується на цей елемент мінерального живлення рослин (В. В. Швартау, 2009). В зв'язку з цим виникає великий розрив між валовим вмістом фосфору в грунті і його доступною кількістю для рослин [9].

Засвоєння рослинами фосфатних аніонів із важкорозчинних сполук проходить лише 3 грунтового розчину - це основне положення фізіології рослин [8]. Засвоєння рослинами фосфору із важкорозчинних фосфоровмісних сполук проходить поступово й фізіологи пояснюють це тим, що кореневі волоски своїми кислими виділеннями (ексудатами) переводять в розчин апатити та фосфорити не в повній мірі. У зв'язку з цим, проблема фосфору в сучасному землеробстві $\epsilon$ досить гострою і тому ми зобов'язані до цього елемента мінерального живлення відноситись 3 особливою увагою й турботою і постійно вести пошуки шляхів найбільш раціонального його використання в агроценозах зернових культур [6]. Основним джерелом мінерального фосфору для рослин в чорноземах звичайних $є$ одно- та двохвалентні аніони ортофосфорної кислоти. Серед наявних у цих грунтах фосфорних сполук рослини найбільш легко засвоюють добре розчинені в воді солі одновалентних катіонів $\mathrm{K}_{2} \mathrm{HPO}_{4}$ i $\mathrm{KH}_{2} \mathrm{PO}_{4}$, а також двозаміщені солі кальцію ортофосфорної кислоти $\mathrm{CaHPO}_{4}$ [5].

Коренева система більш пристосована до поглинання аніона $\mathrm{H}_{2} \mathrm{PO}_{4}^{-}$i дещо гірше вона засвоює $\mathrm{HPO}_{4}{ }^{2-}$, тобто рослини краще засвоюють розчинні в воді дигідрофосфати, ніж гідрофосфати, розчиненні в слабких кислотах, що пов'язано 3 додатковими витратами енергіiі [11]. До того ж аніон $\mathrm{H}_{2} \mathrm{PO}_{4}^{-}$легше адсорбується коренями, ніж $\mathrm{HPO}_{4}{ }^{2-}$, значення якого зростає за високих показників $\mathrm{pH}$, оскільки в розчині $3 \mathrm{pH}$ вище 7,2 цей 


\section{СІЛЬСЬКЕ ГОСПОДАРСТВО. РОСЛИННИЦТВО}

аніон стає домінуючим іоном. Більшість проведених досліджень показали, що швидкість поглинання фосфору є найвищою в діапазоні $\mathrm{pH}$ від 5,0 до 6,6, коли в грунтовому розчині переважає аніон $\mathrm{H}_{2} \mathrm{PO}_{4}^{-}$(Furihata et. al., 1990).

Аніони $\mathrm{PO}_{4}{ }^{3-}$ не мають практичного значення для рослин. Це пов'язано з низькою розчинністю карбонатів кальцію та магнію - $\mathrm{Ca}_{3}\left(\mathrm{PO}_{4}\right)_{2}$, яка $€$ мінімальною і становить 0,33 мг Р в 1 л [12]. $\mathrm{У}$ разі висихання частина дигідро- і гідрофосфатіонів переходить в фосфати кальцію та магнію i рівновага порушується, а під час зволоження грунту, навпаки, відбувається перехід в розчин додаткової кількості фосфат-іонів і рівновага відновлюється. Слід відмітити, що в чорноземах звичайних фіксація аніонів фосфору в основному проходить в результаті їх хімічного зв'язування катіонами кальцію, магнію та алюмінію [10].

За даними агрохімічного обстеження грунтів вміст фосфору в них на 1966-1970 рр. у середньому в Україні становив 7,1 мг/100 г грунту. Слід відмітити, що за вмістом фосфору грунтовий покрив відзначається більшою строкатістю порівняно з азотом. Це зумовлено, насамперед, властивостями лесових грунтоутворюючих порід та регіональними особливостями грунтоутворення, а також рівнем інтенсивності землеробства [14].

За період 1966-1990 рр. обсяги застосування фосфорних добрив постійно зростали. Загальний баланс фосфору в 1971-1975 рр. був позитивним (+3,9 кг/га $\left.\mathrm{P}_{2} \mathrm{O}_{5}\right)$, у наступні періоди (1976-1980 pp.) +10,1 кг/га; 1981-1985 pp. - +15 кг/га; 19861990 pp. $-+20,6$ кг/га $\mathrm{P}_{2} \mathrm{O}_{5}$. За даними агрохімічного обстеження (1991-1995 рр.) площі орних земель 3 підвищеним і високим вмістом фосфору зростали, а з низьким та середнім вмістом залишалися, порівняно $з$ першим туром обстеження (1966-1970 рр.) на рівні $30 \%$. Середньозважений вміст рухомого фосфору в Степу зріс з 6,7 до 9,3 мг на 100 г грунту [8].

Починаючи з 1991 року, рівень внесення фосфорних добрив різко зменшується і в 1997 році дорівнював 4,1 кг/га $\mathrm{P}_{2} \mathrm{O}_{5}$. Дефіцит мінерального фосфору щорічно становить 15-20 кг/га, що зумовлюе зниження вмісту фосфору у грунті на 0,4-0,5 мг/100 г грунту. Це поступово погіршує фосфатний режим чорноземів звичайних. Найнижчу кількість фосфорних добрив було внесено в 2000 році - всього лише 2 кг/га $\mathrm{P}_{2} \mathrm{O}_{5}$. В 2001 та 2002 роках також було внесено невелику кількість цих добрив - 3 кг/га $\mathrm{P}_{2} \mathrm{O}_{5}$ [6].

Поступове нарощування кількості внесених фосфорних добрив розпочалося 32004 року 4 кг/га, аналогічну кількість було внесено в 2005 році. В 2006 році їх уже було внесено 7 кг/га $\mathrm{P}_{2} \mathrm{O}_{5}$, в 2007 p. - 10 кг/га $\mathrm{P}_{2} \mathrm{O}_{5} .32008$ року знову почала спостерігатись тенденція до зменшення обсягів їх внесення, спочатку до 9 кг/га, а потім, в 2009 та 2010 роках - до 7 кг/га $\mathrm{P}_{2} \mathrm{O}_{5}$. Таке тривале внесення невеликих обсягів фосфорних добрив викликало поступове погіршення фосфатного режиму цих грунтів. Згідно з розробленим прогнозом, за повного припинення застосування фосфорних добрив вміст фосфору в грунтах знизиться на 3,0-3,2 мг/100 г грунту, а за таких умов господарювання грунти повністю втратять ту кількість фосфору, яка ними була накопичена за роки інтенсивної хімізації [12].

Слід відмітити, що в великих обсягах фосфорні добрива вносять в грунт лише економічно розвинуті країни, такі як Японія, США, Великобританія, Німеччина, Франція, Данія, Італія, Китай, які постійно нарощують обсяги їх внесення. Причому в Німеччині навіть виникає проблема зафосфачування грунтів. Тому на думку окремих авторів, у разі збереження цієї тенденції й надалі, запаси фосфору на Земній кулі можуть бути вичерпані вже через 60-80 років (Hammond et al., $2003)$ і глобальний пік використання запасів фосфатної сировини за прогнозами деяких дослідників (Jasinski, 2006) буде припадати на 2040 рік [5]. У більшості ж країн світу, зокрема і в Україні, дози внесення цих добрив невисокі й винесення фосфору 3 грунту отриманими врожаями сільськогосподарських культур переважає його надходження з туками. У зв'язку з тим, щоб прослідкувати за змінами, які відбулися з рухомими формами фосфору та порівняти ступінь їх рухомості в чорноземах звичайних на ріллі по відношенню до цілини й виникла необхідність в проведенні досліджень.

Мета дослідження: встановити залежності зміни вмісту рухомого фосфору в генетичних горизонтах чорнозему звичайного.

Завдання дослідження:

1. Визначити природу штучного завищення оцінки фосфатного стану грунту.

2. Уточнити існуючі методики діагностики фосфатного стану грунту.

3. Встановити динаміку формування основного джерела розчинних фосфатів у грунті.

Методика проведення досліджень. Виконання науково-дослідної роботи проводили на Ерастівській дослідній станції ДУ Інституту сільського господарства степової зони НААН України, де грунти - чорноземи звичайні мало- 


\section{СІЛЬСЬКЕ ГОСПОДАРСТВО. РОСЛИННИЦТВО}

гумусні важкосуглинкові на лесі. В орному шарі грунту гумусу міститься 3,8-4,1 \% (метод Тюрина), валового азоту 0,22-0,23, фосфору 0,12-0,13, калію 2,0-2,1 \%. Рівень нітратного азоту після 7денного компостування змінювався від 31 до 52 мг/кг грунту. Рухомого фосфору (за Чириковим) 110-112 мг/кг, рухомого калію 105-130 мг/кг. Реакція грунтового розчину нейтральна $\left(\mathrm{pH}_{\text {водн. }}=\right.$ 7,0) [13].

Для визначення змін, які відбулися з рухомими формами фосфору в чорноземах звичайних під впливом тривалого їх використання в сільськогосподарському виробництві, було зроблено два грунтових розрізи глибиною 2 м, шириною 3 м і довжиною 6 м кожний: перший на цілинній ділянці поблизу села Байківка П'ятихатського району Дніпропетровської області, а другий - на ріллі на відстані 300 м від першого. Розпочинаючи 3 верхньої частини розрізів через кожні 5 см по всій глибині відбирали зразки грунту для визначення вмісту в них рухомих форм фосфору, вміст якого визначали за кислотним методом Чирикова (ГОСТ 26204-91) і сольовим методом Карпінського-Зам'ятиної (ДСТУ 4727:2007) [1, 2]. Визначення оптичної густини розчинів проводили на фотоелектро-колориметрі КФК-2. Мікробіологічні дослідження зразків грунту проведені за загальноприйнятими методиками. Аналізи виконували в трьохкратному аналітичному повторенні.

Результати досліджень. Рілля, яка становить 53,8 \% території України, належить до найбільш нестійких ландшафтів, а недотримання чергування сільськогосподарських культур під час їх вирощування, порушення сівозмін, засилля монокультури та різке зменшення обсягів внесення мінеральних i органічних добрив посилюють агрохімічну нестабільність агроландшафтів. Недотримання науково-обгрунтованих зональних систем землеробства, порушення екологічно допустимого співвідношення посівів сільськогосподарських культур призводять до дефіциту в грунті рухомих форм поживних речовин, збільшують площі деградованих земель і породжують екологічні проблеми [4].

Під час роздержавлення та перерозподілу земель порушилися сівозміни. Згідно з показниками Держкомстату України посівні площі основних сільськогосподарських культур в Україні за 1990-2010 роки зменшилися більш ніж на 7,1 млн га і становлять 24,6 млн га. Водночас посіви зернових і зернобобових культур залишаються на рівні 15 млн га (61\%), проте посіви соняшнику невпинно збільшуються і становлять 4,57 млн га, або $19 \%$ загальної площі посівів. Площа посівів ріпаку щорічно змінюється, але сягає 1,2-1,7 млн га (5-7\%), а посіви кормових культур зменшилися на 9,4 млн га і на їхню частку припадає лише 10,5 \%.

В Україні провідними науковими установами для кожного природно-сільськогосподарського регіону прийняті нормативи оптимального співвідношення культур у сівозмінах, а також терміни повернення окремих культур у сівозміні. Тільки у степових регіонах насичення соняшнику у сівозміні допускається $10-15 \%$, а ріпаку 5$12 \%$. Зіставлення фактичних і нормативних показників співвідношення культур свідчить про масове недотримання сільськогосподарськими підприємствами науково обгрунтованих сівозмін або, навіть, їх відсутність. Посіви ж кон'юнктурних культур призводять до виснаження грунтів, утворення малопродуктивних земель i, в кінцевому підсумку, до їхньої деградації. Площа таких земель щороку збільшується i вже зараз налічує понад 1,4 млн га. Усе це свідчить про неефективне використання земель і відсутність надійної охорони останніх у сільськогосподарських підприємствах [3].

У даній статті наведені зміни, які відбулися 3 рухомими формами фосфору в чорноземах звичайних на ріллі по відношенню до цілини. Об'єктивно оцінити стан та встановити напрям трансформації сучасних еволюційних змін фосфорного режиму чорнозему звичайного дає змогу порівняння цілинних та орних земель за вмістом рухомих форм фосфору, визначених за різними методами в зразках грунту відібраних через кожні 5 см на всю глибину грунтових профілів на цілині та ріллі.

Джерелом надходження фосфору на цілині $є$ відмерлі частини рослин, а на ріллі - добрива та пожнивно-кореневі залишки. Проблема загострюється ще й безповоротністю втрат фосфору, обумовленою виносом цього елемента 3 грунту рослинами, оскільки накопичення його переважає в зерні, а не у вегетативній масі, яка після збирання врожаю в процесі мікробіологічного розкладу поповнює запаси недоступних для рослин елементів. На ріллі основна маса фосфору вилучається $з$ грунту разом з зерном, яке щорічно вивозиться з полів.

У зерні зосереджена основна кількість фосфору $(0,65-0,85 \%)$, яка майже в три-чотири рази перевищує його вміст в листостебловій масі 0,20-0,28 \%) (табл. 1$)$. 
СІЛЬСЬКЕ ГОСПОДАРСТВО. РОСЛИННИЦТВО

\section{1. Порівняльна оцінка вмісту валового фосфору в основній та побічній продукції основних сільськогосподарських культур}

\begin{tabular}{|c|c|c|}
\hline \multirow{2}{*}{ Сільськогосподарська культура } & \multicolumn{2}{|c|}{ Середній вміст фосфору в сухій речовині в (\%) } \\
\cline { 2 - 3 } & еерні & листостебловій масі \\
\hline пшениця озима & 0,85 & 0,20 \\
\hline жито озиме & 0,86 & 0,25 \\
\hline кукурудза & 0,57 & 0,30 \\
\hline ячмінь ярий & 0,85 & 0,20 \\
\hline овес & 0,85 & 0,35 \\
\hline просо & 0,65 & 0,18 \\
\hline сорго & 0,67 & 0,35 \\
\hline горох & 1,0 & 0,35 \\
\hline соя & 1,04 & 0,31 \\
\hline соняшник & 1,39 & 0,65 \\
\hline ріпак & 1,8 & 0,25 \\
\hline
\end{tabular}

Тому залишена на полі вся листостеблова маса не в змозі в повній мірі компенсувати винесеного з врожаєм зерна фосфору. Для того, щоб у грунті не виникав від'ємний баланс фосфору, в нього потрібно повертати цей важливий елемент мінерального живлення разом 3 фосфоровмісними добривам. Тому забезпечення грунту фосфором у даний час може здійснюватись в основному лише за рахунок внесення фосфорних добрив.

За останні 25 років кількість внесеного фосфору на 1 га посівної площі знизилась із 40 кг діючої речовини до 3-4, азоту - 360 до 5-15, калію - 335 до 1-2 кг діючої речовини. В останнє десятиліття виробництво фосфорних добрив в Україні різко скоротилося (Щегров, 2001), зокрема у 2005 році знизилося на 22,9 \%, що і призвело до різкого падіння рівня застосування мінеральних фосфорних добрив. Така ситуація пов'язана $з$ їхньою високою вартістю, зумовленою зростанням цін на енергоносії і обмеженістю джерел власної фосфатної сировини для їхнього виробництва.

Одним зі шляхів вирішення проблеми фосфорного живлення $\epsilon$ широке використання фосфоритів місцевих родовищ. Україна має значну кількість родовищ фосфоритів (Волинська, Ізюмсько-Донецька групи родовищ та інші), поклади яких приурочені до відкладів нижнього кембрію, верхньої крейди та палеогену. В західному Поліссі вже розвідано родовища зернистих та жовнових фосфоритів у складі агроруди, поклади якої залягають від 10 до 20 м, іноді ближче до поверхні [17]. Але через невисоку концентрацію в них $\mathrm{P}_{2} \mathrm{O}_{5}$ ці фосфорити не переробляються на суперфосфат та інші водороз- чинні фосфорні добрива і тому для виробництва фосфорних добрив в основному використовується імпортна сировина, що обумовлює високу їх вартість.

У більшості ж випадків українські фосфорити містять у своєму складі до $5 \% \mathrm{P}_{2} \mathrm{O}_{5}$ або $12-15 \%$ фосфоритнокальцієвих мінералів та фосфатизованих їх порід i тому потребують проведення додаткового їх збагачення після проведення якого буде суттєво зростати вартість фосфорних добрив. У зв'язку з цим ці фосфорити використовують лише на кислих грунтах Полісся та Карпат і на слабокислих грунтах лісостепової зони: у кислому середовищі слаборозчинні фосфати легко розчиняються [15].

На грунтах 3 нейтральною реакцією грунтового розчину фосфати практично не засвоюються корінням рослин і їх там практично не застосовують. На цих грунтах слід надати перевагу водорозчинним тукам.

Враховуючи порушення паритету цін на сільськогосподарську продукцію й добрива, обсяги внесення фосфорних добрив в нашій державі невисокі. В основному їх вносять під час сівби в невеликій дозі $\mathrm{P}_{10}$. Зважаючи на невисоку природну забезпеченість більшості грунтів рухомими сполуками фосфору, спостерігається різке падіння ефективної родючості грунтів, погіршується режим фосфорного живлення рослин, що в результаті призводить до зниження врожайності сільськогосподарських культур.

Порівняльний аналіз вмісту рухомого фосфору в цих двох грунтових профілях переконливо показав їх накопичення в верхніх шарах грунту в порівнянні з розташованими глибше. Це, перш за все, пов'язано з біологічною акумуляцією фосфо- 


\section{СІЛЬСЬКЕ ГОСПОДАРСТВО. РОСЛИННИЦТВО}

ру кореневими системами рослин. Така біологічна акумуляція проходить у результаті діяльності коренів рослин, які за рахунок своїх ексудатів розчиняють фосфати кальцію і магнію, переводячи їх в гідро- та дигідрофосфати і нагромаджують цей елемент мінерального живлення в поверхневих горизонтах грунту.

Аніон $\mathrm{PO}_{4}{ }^{3-}$ в грунті міститься в органічних комплексах (нуклеопротеїди, фосфатиди) і в різних співвідношеннях 3 катіонами $\mathrm{Ca}^{2+}, \mathrm{Mg}^{2+}$, $\mathrm{Fe}^{2+}, \mathrm{Fe}^{3+}, \mathrm{Al}^{3+}$. Ці фосфати в різній мірі доступні кореням рослин. Зміни вмісту загального фосфору у грунті на цілинних та орних ділянках притаманні лише верхньому (0-10 см) шару 0,164 i 0,148 \%. Починаючи 3 шару грунту 10-20 см та глибше по профілю, його запаси знаходились на одному рівні. Тому в своїх дослідженнях основна наша увага зосереджена на рухомих формах фосфору, які в більшості випадках є лімітуючим фактором для росту, розвитку рослин та формування урожайності сільськогосподарських культур.

Мобілізація фосфору з важкорозчинних природних сполук відбувається переважно під дією продуктів метаболізму мікроорганізмів. Особливого значення набувають бактерії, що мають потенційну здатність перетворювати важкорозчин-

ні фосфати грунту у доступну для рослин форму. Важливе місце серед них посідають грунтові бактерії Rhizobiumradiobacter, які окрім фосфатмобілізувальної активності здатні ще й до асоціативної азотфіксації (Муромцев Г. С. та ін., 1985; Павлов В. Ф., 1987; Чумаков М. І., 1992; Панюта О. А., Белава В. Н., Токмакова Л. Н., 2011).

Відомо, що одним із чинників розчинення важкорозчинних мінеральних фосфатів є підкислення грунтового розчину, а гідроліз органофосфатів, за впливу бактерій, пов'язаний з дією специфічних ферментів - фосфатаз. Вченими (Токмакова Л. М. та Трепач А. О., 2012) встановлено, що бактерії $R$. radiobacterє активними продуцентами ацетатної, масляної та інших органічних кислот, під впливом яких проходить переведення в грунтовий розчин слабкорозчинних фосфатів кальцію та магнію.

Встановлено, що фосфатозна активність бактерій становить від $0,17 \quad \mathrm{P}_{2} \mathrm{O}_{5}$ кмоль/мл/год. (R. Radiobacter 5005) до 2,35 $\mathrm{P}_{2} \mathrm{O}_{5}$ кмоль/мл/год. (R. Radiobacter 5006).

Проведені нами дослідження показали, що найвищою чисельністю фосфатмобілізуючих бактерій характеризується верхній гумусовий горизонт цілині (табл. 2).

\section{2. Чисельність фосфатмобілізуючих бактерій у зразках трунту відібраних у трунтовому розрізі на цілині та ріллі чорнозему звичайного (околиця с. Байківка Пятихатського району Дніпропетровської області)}

\begin{tabular}{|c|c|c|}
\hline \multirow{3}{*}{ Шари грунту, см } & \multicolumn{2}{|c|}{ Фосфатмобілізувальні бактерії, млн/г } \\
\hline & \multicolumn{2}{|c|}{ що розчиняють } \\
\hline & мінеральні фосфати & органофосфати \\
\hline \multicolumn{3}{|c|}{ Рілля } \\
\hline $0-5$ & $1,5 \pm 0,1$ & $5,4 \pm 0,4$ \\
\hline $5-10$ & $1,3 \pm 0,1$ & $2,3 \pm 0,1$ \\
\hline $10-15$ & $1,3 \pm 0,1$ & $2,7 \pm 0,2$ \\
\hline $15-25$ & $2,2 \pm 0,2$ & $2,4 \pm 0,2$ \\
\hline $25-35$ & $1,2 \pm 0,1$ & $4,5 \pm 0,3$ \\
\hline $35-45$ & $1,4 \pm 0,1$ & $1,0 \pm 0,0$ \\
\hline $45-65$ & $0,6 \pm 0,1$ & $1,0 \pm 0,1$ \\
\hline \multicolumn{3}{|c|}{ Цілина } \\
\hline $0-5$ & $6,8 \pm 0,3$ & $9,8 \pm 0,6$ \\
\hline $5-10$ & $2,5 \pm 0,2$ & $4,7 \pm 0,4$ \\
\hline $10-15$ & $2,2 \pm 0,1$ & $2,2 \pm 0,2$ \\
\hline $15-25$ & $1,5 \pm 0,1$ & $2,0 \pm 0,1$ \\
\hline $25-35$ & $1,2 \pm 0,1$ & $2,5 \pm 0,3$ \\
\hline $35-45$ & $0,8 \pm 0,1$ & $1,2 \pm 0,1$ \\
\hline $45-65$ & $1,2 \pm 0,2$ & $0,9 \pm 0,0$ \\
\hline
\end{tabular}


СІЛЬСЬКЕ ГОСПОДАРСТВО. РОСЛИННИЦТВО

\section{3. Вміст рухомого фосфору в різних ценозах чорнозему звичайного за даними кислотного} та сольового методів

\begin{tabular}{|c|c|c|c|c|}
\hline \multirow{2}{*}{$\begin{array}{l}\text { Шари } \\
\text { грунту, } \\
\text { см }\end{array}$} & \multicolumn{2}{|c|}{$\begin{array}{c}\text { Вміст рухомого фосфору } \\
\text { за Чириковим } \\
\text { (мг } \mathrm{P}_{2} \mathrm{O}_{5} / \text { кг грунту) }\end{array}$} & \multicolumn{2}{|c|}{$\begin{array}{c}\text { Вміст рухомого фосфору } \\
\text { за Карпінським-Зам'ятіною } \\
\left.\text { (мг } \mathrm{P}_{2} \mathrm{O}_{5} / л\right)\end{array}$} \\
\hline & рілля & цілина & рілля & цілина \\
\hline $0-5$ & 167 & 163 & 0,19 & 0,14 \\
\hline $6-10$ & 167 & 112 & 0,18 & 0,13 \\
\hline $11-15$ & 169 & 92 & 0,18 & 0,10 \\
\hline $16-20$ & 168 & 96 & 0,17 & 0,09 \\
\hline $21-25$ & 172 & 88 & 0,14 & 0,09 \\
\hline $26-30$ & 164 & 83 & 0,19 & 0,08 \\
\hline $31-35$ & 137 & 80 & 0,15 & 0,04 \\
\hline $36-40$ & 112 & 78 & 0,11 & 0,04 \\
\hline $41-45$ & 92 & 77 & 0,11 & 0,09 \\
\hline $46-50$ & 94 & 75 & 0,11 & 0,09 \\
\hline $51-55$ & 107 & 64 & 0,10 & 0,06 \\
\hline $56-60$ & 54 & 79 & 0,10 & 0,12 \\
\hline $61-65$ & 53 & 88 & 0,08 & 0,10 \\
\hline $66-70$ & 59 & 53 & 0,07 & 0,09 \\
\hline $71-75$ & 53 & 58 & 0,11 & 0,07 \\
\hline $76-80$ & 62 & 39 & 0,10 & 0,07 \\
\hline $81-85$ & 56 & 41 & 0,10 & 0,11 \\
\hline $86-90$ & 54 & 36 & 0,10 & 0,10 \\
\hline $91-95$ & 50 & 35 & 0,12 & 0,08 \\
\hline $96-100$ & 51 & 34 & 0,12 & 0,07 \\
\hline $101-105$ & 50 & 34 & 0,11 & 0,11 \\
\hline $106-110$ & 50 & 35 & 0,10 & 0,11 \\
\hline $111-115$ & 50 & 38 & 0,13 & 0,11 \\
\hline $116-120$ & 48 & 38 & 0,12 & 0,12 \\
\hline $121-125$ & 48 & 39 & 0,12 & 0,12 \\
\hline $126-130$ & 48 & 39 & 0,11 & 0,11 \\
\hline $131-135$ & 49 & 39 & 0,11 & 0,10 \\
\hline $136-140$ & 51 & 40 & 0,12 & 0,10 \\
\hline $141-145$ & 52 & 40 & 0,12 & 0,11 \\
\hline $146-150$ & 49 & 41 & 0,13 & 0,10 \\
\hline $151-155$ & 50 & 40 & 0,12 & 0,10 \\
\hline $156-160$ & 53 & 40 & 0,12 & 0,10 \\
\hline $161-165$ & 57 & 40 & 0,11 & 0,08 \\
\hline $166-170$ & 62 & 42 & 0,13 & 0,08 \\
\hline $171-175$ & 73 & 42 & 0,13 & 0,07 \\
\hline $176-180$ & 77 & 44 & 0,12 & 0,06 \\
\hline $181-185$ & 69 & 45 & 0,12 & 0,06 \\
\hline $186-190$ & 73 & 48 & 0,13 & 0,10 \\
\hline $191-195$ & 74 & 52 & 0,13 & 0,10 \\
\hline $196-200$ & 78 & 55 & 0,13 & 0,09 \\
\hline
\end{tabular}




\section{4. Фосфатний стан орного шару неудобрених чорноземів звичайних важкого транулометричного} складу Північного Степу Украӥни

\begin{tabular}{|c|c|c|c|c|c|c|}
\hline \multicolumn{7}{|c|}{ Вміст $\mathrm{P}_{2} \mathrm{O}_{5}$ за: } \\
\hline \multirow{2}{*}{$\begin{array}{l}\text { Р вал., } \\
\text { мг/кг }\end{array}$} & \multirow{2}{*}{$\begin{array}{c}\text { Чириковим, } \\
\text { мг/кг }\end{array}$} & \multirow{2}{*}{$\begin{array}{c}\text { Карпінським- } \\
\text { Зам'ятіною, } \\
\text { мг/л }\end{array}$} & \multicolumn{4}{|c|}{ Chang, Jackson } \\
\hline & & & $\begin{array}{c}\text { Р пухкий, } \\
\text { Мг/кг }\end{array}$ & $\begin{array}{l}\mathrm{Al}-\mathrm{P}, \\
\mathrm{M \Gamma} / \mathrm{K} \Gamma\end{array}$ & $\begin{array}{l}\mathrm{Fe}-\mathrm{P}, \\
\mathrm{M \Gamma} / \mathrm{K} \Gamma\end{array}$ & $\begin{array}{l}\mathrm{Ca}-\mathrm{P} \\
\mathrm{M \Gamma} / \mathrm{K \Gamma}\end{array}$ \\
\hline 1060 & 107 & 0,06 & 4,7 & 55 & 78 & 245 \\
\hline 1230 & 89 & 0,03 & 5,0 & 37 & 8 & 250 \\
\hline 1330 & 103 & 0,05 & 2,3 & 42 & 49 & 170 \\
\hline 1370 & 115 & 0,06 & 3,0 & 64 & 12 & 276 \\
\hline- & 126 & 0,05 & 5,2 & 31 & 72 & 304 \\
\hline 1430 & 91 & 0,05 & 5,5 & 30 & 73 & 358 \\
\hline 1550 & 113 & 0,06 & 6,0 & 62 & 106 & 367 \\
\hline- & 106 & 0,04 & 2,8 & 50 & 68 & 221 \\
\hline
\end{tabular}

4. Вилив компостування на вміст $P_{2} O_{5}$ у зразках трунту, відібраних на цілині та староорній ділянці поля (мг/100 г трунту; середнє з трьох повторень)

\begin{tabular}{|c|c|c|c|c|c|c|c|c|}
\hline \multirow[b]{3}{*}{$\begin{array}{c}\text { Шари } \\
\text { грунту, см }\end{array}$} & \multicolumn{8}{|c|}{ Методи визначення $\mathrm{P}_{2} \mathrm{O}_{5}, \mathrm{Mr} / 100$ г грунту } \\
\hline & \multicolumn{4}{|c|}{ Чирикова } & \multicolumn{4}{|c|}{ Карпінського-Зам'ятіної } \\
\hline & $\begin{array}{c}\text { до ком- } \\
\text { пос- } \\
\text { туван- } \\
\text { ня } \\
\end{array}$ & $\begin{array}{c}\text { після } \\
\text { 10-денного } \\
\text { компос- } \\
\text { тування }\end{array}$ & $\begin{array}{c}\text { після } \\
20 \text {-денного } \\
\text { компос- } \\
\text { тування }\end{array}$ & $\begin{array}{c}\text { після } \\
\text { 30-денного } \\
\text { компос- } \\
\text { тування }\end{array}$ & \begin{tabular}{|c} 
до ком- \\
пос- \\
туван- \\
ня \\
\end{tabular} & $\begin{array}{c}\text { після } \\
10 \text {-денного } \\
\text { компос- } \\
\text { тування } \\
\end{array}$ & $\begin{array}{c}\text { після } \\
20 \text {-денного } \\
\text { компос- } \\
\text { тування } \\
\end{array}$ & $\begin{array}{c}\text { після 30- } \\
\text { денного } \\
\text { компос- } \\
\text { тування }\end{array}$ \\
\hline \multicolumn{9}{|c|}{ цілинна ділянка поля } \\
\hline $0-5$ & 16,3 & 22,3 & 22,6 & 22,0 & 0,14 & 0,52 & 0,40 & 0,33 \\
\hline $6-10$ & 11,2 & 19,0 & 22,3 & 21,7 & 0,13 & 0,50 & 0,29 & 0,34 \\
\hline $11-15$ & 9,2 & 14,4 & 20,7 & 19,2 & 0,10 & 0,50 & 0,26 & 0,30 \\
\hline $16-20$ & 9,6 & 17,0 & 19,7 & 18,8 & 0,09 & 0,46 & 0,23 & 0,27 \\
\hline $21-25$ & 8,8 & 17,7 & 19,2 & 18,4 & 0,09 & 0,48 & 0,24 & 0,24 \\
\hline $26-30$ & 8,3 & 18,0 & 18,6 & 18,0 & 0,08 & 0,38 & 0,22 & 0,24 \\
\hline \multicolumn{9}{|c|}{ староорна ділянка поля } \\
\hline $0-5$ & 16,7 & 22,9 & 25,9 & 27,7 & 0,19 & 0,58 & 0,32 & 0,35 \\
\hline $6-10$ & 16,7 & 18,3 & 26,7 & 28,9 & 0,18 & 0,56 & 0,31 & 0,34 \\
\hline $11-15$ & 16,9 & 22,6 & 26,2 & 27,9 & 0,18 & 0,50 & 0,31 & 0,32 \\
\hline $16-20$ & 16,8 & 22,9 & 25,9 & 27,7 & 0,17 & 0,62 & 0,30 & 0,29 \\
\hline $21-25$ & 17,2 & 23,6 & 25,5 & 27,4 & 0,14 & 0,54 & 0,29 & 0,26 \\
\hline $26-30$ & 16,4 & 24,7 & 25,3 & 26,2 & 0,19 & 0,52 & 0,31 & 0,25 \\
\hline
\end{tabular}

Поряд $з$ цим слід відзначити, що за внесення в грунт високих доз азотних добрив відбувається підкислення грунтового розчину та зростає ступінь рухомості фосфатів. Вивчення фосфатного стану чорнозему звичайного показало наступне: згідно 3 даними нормативного документа колишнього СРСР (метод Чирикова), верхні горизонти, як агро- так і біогеоценозу характеризуються високою забезпеченістю фосфором - відповідно 167 і 163 мг $\mathrm{P}_{2} \mathrm{O}_{5} /$ кг грунту (табл. 2).

Аналіз грунтів, проведений за національним стандартом України (метод КарпінськогоЗамя'тіної) показав, що дана оцінка родючості грунтів $\epsilon$ хибною і ці ценози характеризуються лише середньою забезпеченістю фосфором. Це пояснюють добре відомі емпіричні дані про високу ефективність фосфорних добрив на чорноземних грунтах.

Розбіжність в оцінці фосфатного стану пояснюється наступним: раніше проведеними дослідженнями було встановлено, що чорноземи важкосуглинкового і глинистого гранулометричного 


\section{СІЛЬСЬКЕ ГОСПОДАРСТВО. РОСЛИННИЦТВО}

складу на лесових породах містять підвищену або високу кількість апатитоподібних сполук фосфору - понад 200 мг $\mathrm{P}_{2} \mathrm{O}_{5}$ / кг (фракція Сa-P, метод Chang, Jackson) (табл. 3).

Фосфор, що міститься в цих мінералах, рослинам безпосередньо не доступний, але частково екстрагується розчинами сильних кислот, у тому числі 0,5 н оцтовою кислотою (метод Чирикова), саме це i призводить до істотного завищення оцінки фосфатного стану грунтів.

Використання стандарту України показує, що реальний природний вміст рухомого фосфору в цих грунтах відповідає, так званому, рівню динамічної рівноваги, тобто 0,04-0,06 мг/л (табл. 4). Згідно 3 вимогами нормативних документів України, вміст рухомого фосфору в грунтах зони Степу слід визначати одним 3 трьох методів: Карпінського-Зам'ятіної, Мачигіна (ДСТУ 4114) або Olsen (ДСТУ ISO 11263). Вміст рухомого фосфору у досліджуваних ценозах чорнозему звичайного дещо вище рівня динамічної рівноваги фосфатних систем грунтів - 0,17-0,19 мг $\mathrm{P}_{2} \mathrm{O}_{5} /$ л у ріллі і $0,13-0,14$ мг $\mathrm{P}_{2} \mathrm{O}_{5} / л$ в шарі 10 см цілини (табл. 2). Для ріллі дане підвищення пояснюється наявністю залишкових фосфатів добрив. Тобто цей грунт $є$ малоудобреним.

Що стосується цілини, то можна відмити наступне: завдяки комплексу біохімічних, хімічних, фізико-хімічних і інших процесів, характерних для верхнього гумусового горизонту цілинних і перелогових грунтів їх фосфатні системи характеризуються підвищеною кількістю вільної енергіï. Безумовно, основним джерелом цієї енеprii, що компенсує виробіток ентропії під час біологічних і хімічних процесів, є органічна речовина. Дані сполуки нейтралізують позитивні заряди на поверхні глинистих мінералів, зв'язують активні катіони заліза, алюмінію і блокують фіксацію аніонів фосфорної кислоти.

Тому цей горизонт даних біогеоценозів характеризується, як правило, підвищеною, або високою забезпеченістю фосфором.

Фосфатний стан нижніх горизонтів обох ценозів практично однаковий і відповідає рівню динамічної рівноваги. Наявність більш високого вмісту рухомого фосфору в окремих шарах грунту $\left(0,10-0,12\right.$ мг $\left.\mathrm{P}_{2} \mathrm{O}_{5} / л\right)$ створюється за рахунок наявності карбонатів кальцію. Внаслідок появи цих сполук нейтральне значення сольової витяжки (рН-5,8) зсувається в лужну сторону, що підвищує іï екстрагуючу здатність.

Вміст рухомих форм фосфору в грунті залежить від багатьох факторів у тому числі і від рівня його зволоження, що пов'язано $з$ різною ак- тивністю біоти. Так, у разі підсихання грунту вміст рухомих форм фосфору зменшується, а після зволоження спостерігається тенденція до його зростання. Ця закономірність досить часто спостерігається в посушливі роки, коли під час висихання грунту, доступність фосфору знижується через швидке формування нерозчинних комплексів аніонів $\left(\mathrm{PO}_{4}{ }^{3-}, \mathrm{HPO}_{4}{ }^{2-}, \mathrm{H}_{2} \mathrm{PO}_{4}{ }^{-}\right)$із катіонами (CaO, Fe, Al та інші) (Abel et. al., 2002; Bolland, Gilkes, 1998) та за рахунок включення його в органічні сполуки мікроорганізмами (Marschner et. al., 2005, 2004).

Тому коефіцієнт використання фосфору із мінеральних добрив навіть за достатнього його внесення становить лише 10-20\%, тоді, як азоту - до 50 \%, калію - до 70 \% (Vance, 2001). Низька температура грунту $\left(<10^{\circ} \mathrm{C}\right)$ спричинює нестачу фосфору для рослин навіть за високого їх вмісту в валовій формі.

За низької температури підвищується в’язкість грунтового розчину і знижується інтенсивність його поглинання 3 грунтового розчину кореневою системою рослин. Підвищення температури в грунтовому розчині на $1-2{ }^{\circ} \mathrm{C}$ призводить до збільшення вмісту фосфору в грунтовому розчині на $2 \%$. За нестачі вологи засвоєння фосфору 3 грунту уповільнюється.

Для того, щоб простежити за нагромадженням рухомого фосфору, нами були створені сприятливі умови щодо зволоження $60 \%$ від повної вологоємкості і сприятливий температурний режим $28,5^{\circ} \mathrm{C}$.

За таких умов проводилось компостування в термостаті грунтових зразків, відібраних з різних генетичних горизонтів.

У цих зразках через 10, 20 та 30 діб проводилось визначення рухомих форм фосфору за методом Чирикова, а ступінь їх рухомості визначалась за методом Карпінського-Зам'ятіної. Виконані дослідження показали, що найбільш інтенсивно відбувалось накопичення рухомих форм фосфору в перші 10 діб, в меншій мірі - через 20 діб, а після 30-ти діб компостування спостерігалась тенденція до зменшення вмісту в грунті вищеназваних форм фосфору (табл. 4).

Для більш інформаційного аналізу процесів трансформування показників фосфорного балансу у чорноземах на ріллі необхідно залучити такий інтенсивний показник, як фосфатний потенціал. Фосфатний потенціал можливо виразити 3 розчинності монокальційфосфату у рівноважному розчині гетерогенної системи: тверда фаза грунтовий розчин.

Додаток розчинності монокальційфосфату має 
вираз:

$$
\mathrm{DP}\left(\mathrm{Ca}\left(\mathrm{H}_{2} \mathrm{PO}_{4}\right)_{2}\right)=a_{\mathrm{Ca}^{2+}} \cdot a_{\mathrm{H}_{2} \mathrm{PO}_{4}^{-}}^{2},
$$

де $a_{\mathrm{Ca}}^{2+}, a_{\mathrm{H}_{2} \mathrm{PO}_{4}^{-}}-$концентрація (активність) іонів кальцію та залишку ортофосфорної кислоти. Рівняння (1) після знаходження квадратного кореня та логарифмування має вигляд:

$$
\lg \sqrt{D P_{C a\left(\mathrm{H}_{2} \mathrm{PO}_{4}\right)_{2}}}=0,5 \cdot \lg a_{\mathrm{Ca}^{2+}}+\lg a_{\mathrm{H}_{2} \mathrm{PO}_{4}}
$$

$$
\text { Якщо прийняти }-\lg a_{\mathrm{Ca}^{2+}}=p \mathrm{Ca} \text {, }
$$

$-\lg \mathrm{H}_{2} \mathrm{PO}_{4}=\mathrm{pH}_{2} \mathrm{PO}_{4}$, то праву частину рівняння (2) можливо виразити як:

$$
0,5 \mathrm{pCa}+\mathrm{pH}_{2} \mathrm{PO}_{4}
$$

Сума (3) має назву фосфатного потенціалу, тобто виражає здатність до розчинення монокальційфосфату $\mathrm{Ca}\left(\mathrm{H}_{2} \mathrm{PO}_{4}\right)_{2}$.

Застосовуючи рівняння (3), можливо порівняти значення експериментально здобутих показників $\mathrm{pH}_{2} \mathrm{PO}_{4}$ реальних грунтових розчинів з показниками фосфатного потенціалу.

Якщо значення $\mathrm{pH}_{2} \mathrm{PO}_{4}$ знайдених показників будуть більше відповідного показника фосфатного потенціалу, то динамічна рівновага $\mathrm{H}_{2} \mathrm{PO}_{4}^{-}$ у грунтовому розчині формується більш важкорозчинною сполукою ортофосфорної кислоти, ніж монокальційфосфат.

Для розрахунків значень $\mathrm{pH}_{2} \mathrm{PO}_{4}$ у грунтовому розчині розроблена відповідна схема, яка основана на побудові регресійної залежності $\mathrm{pH}_{2} \mathrm{PO}_{4}$ від значень, сформованих $\mathrm{pH}$ у грунтовій витяжці $0,01 \mathrm{MCaCl}_{2}$.

Для побудови діаграм розчинності залучили низку достатньо апробованих регресійних рівнянь (по Ліндсею і Морено):

Гідроксилапатит $\mathrm{pH}_{2} \mathrm{PO}_{4}=2,33 \mathrm{pH}-8,25$

Варіециіт $\mathrm{pH}_{2} \mathrm{PO}_{4}=10,7-\mathrm{pH}$ (4)

Октокальційфосфат $\mathrm{pH}_{2} \mathrm{PO}_{4}=1,67 \mathrm{pH}-6,24$

Штренгіт $\mathrm{pH}_{2} \mathrm{PO}_{4}=10,9-\mathrm{pH}$

Фторапатит $\mathrm{pH}_{2} \mathrm{PO}_{4}=2 \mathrm{pH}-4,12$

Дикальційфосфат $\mathrm{pH}_{2} \mathrm{PO}_{4}=\mathrm{pH}-2,54$

Прикладом принципів, які покладено в основу формування рівнянь (4), можуть бути розрахунки щодо дикальційфосфату. Для цього необхідно залучити поняття додатку розчинності:

$$
\mathrm{DP}\left(\mathrm{CaHPO}_{4} \cdot 2 \mathrm{H}_{2} \mathrm{O}\right)=a_{\mathrm{Ca}^{2+}} \cdot a_{\mathrm{HPO}_{4}^{-}} \cdot a_{\mathrm{H}_{2} \mathrm{O}}^{2}(5)
$$

Молекулярна маса цієї сполуки становить 172 , в тому числі $\mathrm{Ca}-24 \%, \mathrm{HPO}_{4}-56 \%, \mathrm{H}_{2} \mathrm{O}-$ $21 \%$.

У 100 мл розчинника повністю розчиняється
20 мг дикальційфосфату, що відповідає молярному складу: $\mathrm{Ca}-4,65 \cdot 10^{-3}$ моль; $\mathrm{HPO}_{4}-1,12 \cdot 10^{-2}$ моль; $\mathrm{H}_{2} \mathrm{O}-4,19 \cdot 10^{-3}$ моль.

Значення в цілому додатка у рівнянні (5) становить $2,1710^{-7}$. Значення

$$
p\left(\mathrm{CaHPO}_{4} \cdot 2 \mathrm{H}_{2} \mathrm{O}\right)=-\lg \left(2.17 \cdot 10^{-7}\right)=6.66
$$

3 іншого боку,

$$
p\left(\mathrm{CaHPO}_{4}\right)=p \mathrm{Ca}+p\left(\mathrm{HPO}_{4}\right)=6.66 \text {. 3а- }
$$

лучивши константу рівноваги:

$$
k_{2}=\frac{\left[\mathrm{H}^{+} \rrbracket \mathrm{HPO}_{4}^{-2}\right]}{\left[\mathrm{H}_{2} \mathrm{PO}_{4}^{-}\right]}
$$

отримуємо $p\left(\mathrm{HPO}_{4}\right)=p\left(\mathrm{HPO}_{4}\right)-\mathrm{pH}+\mathrm{pk}_{2}$, де

$\mathrm{k}_{2}$ - це друга за рахунком константа рівноваги у процесі дисоціації ортофосфорної кислоти:

$\left[\mathrm{H}_{3} \mathrm{PO}_{4}\right] \stackrel{k_{1}}{\longrightarrow}\left[\mathrm{H}^{+}\left[\mathrm{H}_{2} \mathrm{PO}^{-}{ }_{4}\right] ;\left[\mathrm{H}_{2} \mathrm{PO}_{4}^{-}\right] \stackrel{k_{2}}{\longrightarrow}\left[\mathrm{H}^{+} \rrbracket\left[\mathrm{HPO}^{-2}{ }_{4}\right]\right.\right.$ $p k_{2}=7,21$.

$p C a^{2+}=2$ для $0,01 \mathrm{MCaCl}_{2}$.

Залучивши вираз $\mathrm{pPO}_{4} 3$ (7) до (6) з урахуванням $\mathrm{pk}_{2}$, отримаємо рівняння:

$$
p \mathrm{H}_{2} \mathrm{PO}_{4}=p H-2.54 \text {. }
$$

У наших дослідженнях була застосована відповідна схема:

- 4 г грунтової наважки заливали 100 мл 0,01 М розчину $\mathrm{CaCl}_{2}$,

- за допомогою $\mathrm{HCl}$ формували шість значень $\mathrm{pH}$ у кожній з витяжок відповідного горизонту 0-30,0 см, 50-70 см,

- після 1 години екстрагування на ротаторі визначали вміст фосфору у фільтраті у перерахунку на $\mathrm{P}_{2} \mathrm{O}_{5}$ та $\mathrm{H}_{2} \mathrm{PO}_{4}$,

- згідно 3 рівнянням (3) розраховували значення $\mathrm{pH}_{2} \mathrm{PO}_{4}=-\lg a_{\mathrm{H}_{2} \mathrm{PO}_{4}} \mathrm{i}$ будували графічний вираз залежності $\left.\left(\mathrm{P}_{2} \mathrm{H}_{2} \mathrm{PO}_{4}\right)=f(p H)\right)$. Регресійну формулу співвідносили 3 переліком (4). На рисунках 1-4 наведені результати графічних побудов.

Таким чином, дослідження, проведені 3 використанням сучасних методів грунтової діагностики показали, що реальна природна забезпеченість фосфором чорноземів звичайних Північного Степу України є невисокою, що лімітує отримання високих урожаїв сільськогосподарських культур.

Внаслідок цього дані грунти так само потребують внесення фосфорних добрив, як i інші грунти України. 

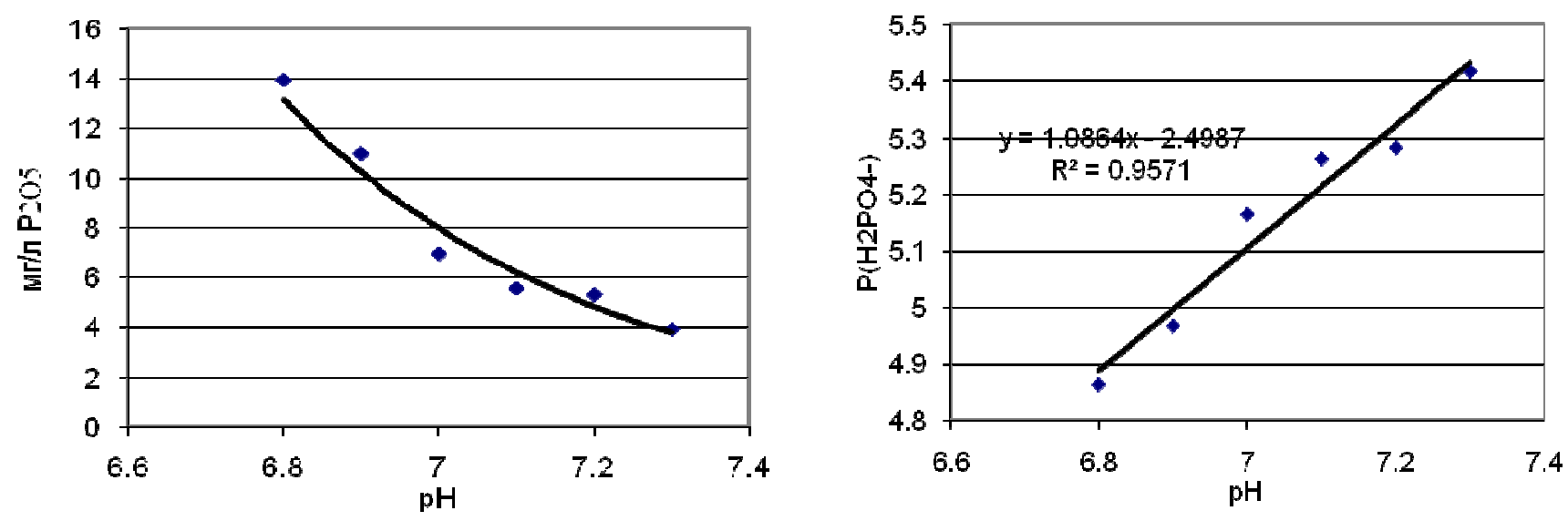

(a) (б)

Рис. 1. Концентраційні залежності вмісту фосфатів у шарі трунту 0-30 см у рівноважному трунтовому розчині чорноземів звичайних на ріллі:

$a$ - залежність вмісту $\mathrm{P}_{2} \mathrm{O}_{5}$ від значень $\mathrm{pH}$;

б - залежність значень $\mathrm{pH}_{2} \mathrm{PO}_{4}$ відповідних витяжок від $\mathrm{pH}$
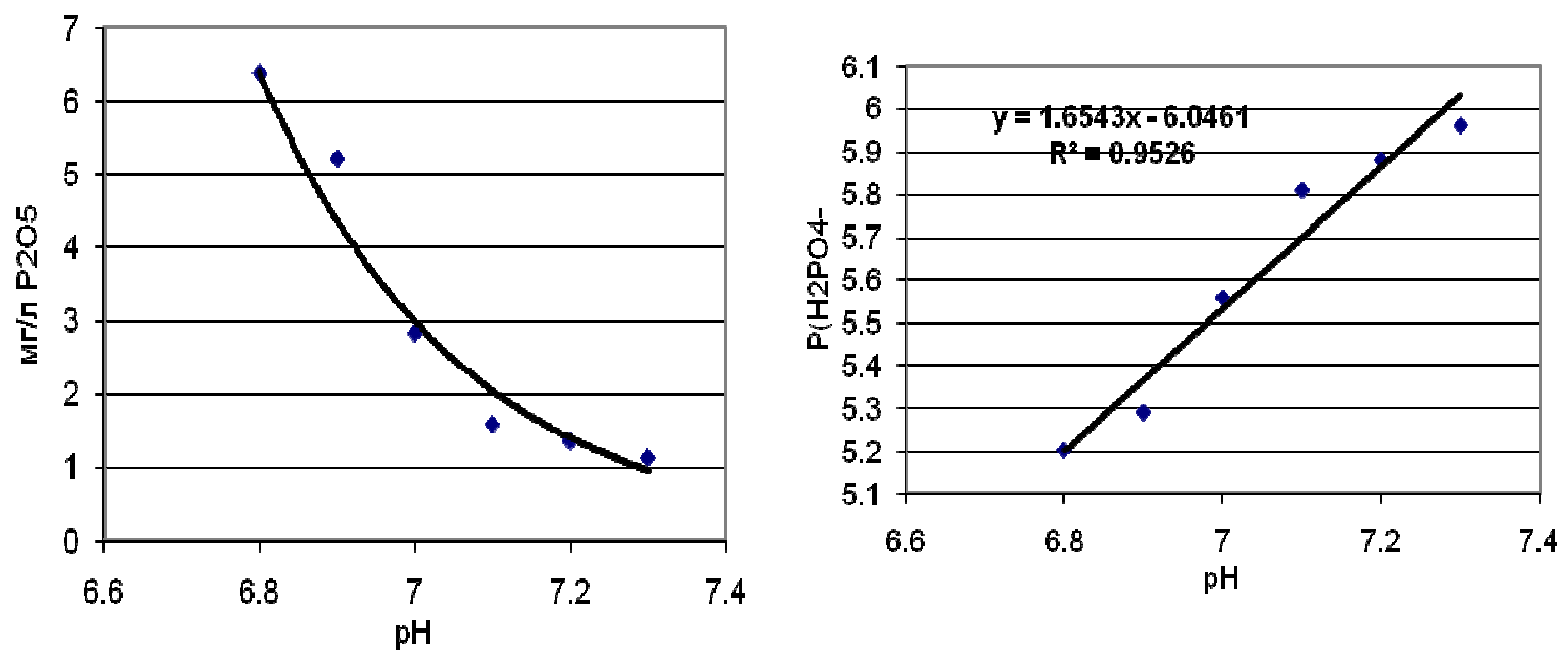

(a) (б)

Рис. 2. Концентраційні залежності вмісту фосфатів у шарі трунту 0-30 см у рівноважному трунтовому розчині чорноземів звичайних на цілині:

$a$ - залежність вмісту $\mathrm{P}_{2} \mathrm{O}_{5}$ від значень $\mathrm{pH}$;

б - залежність значень $\mathrm{pH}_{2} \mathrm{PO}_{4}$ відповідних витяжок від $\mathrm{pH}$. 

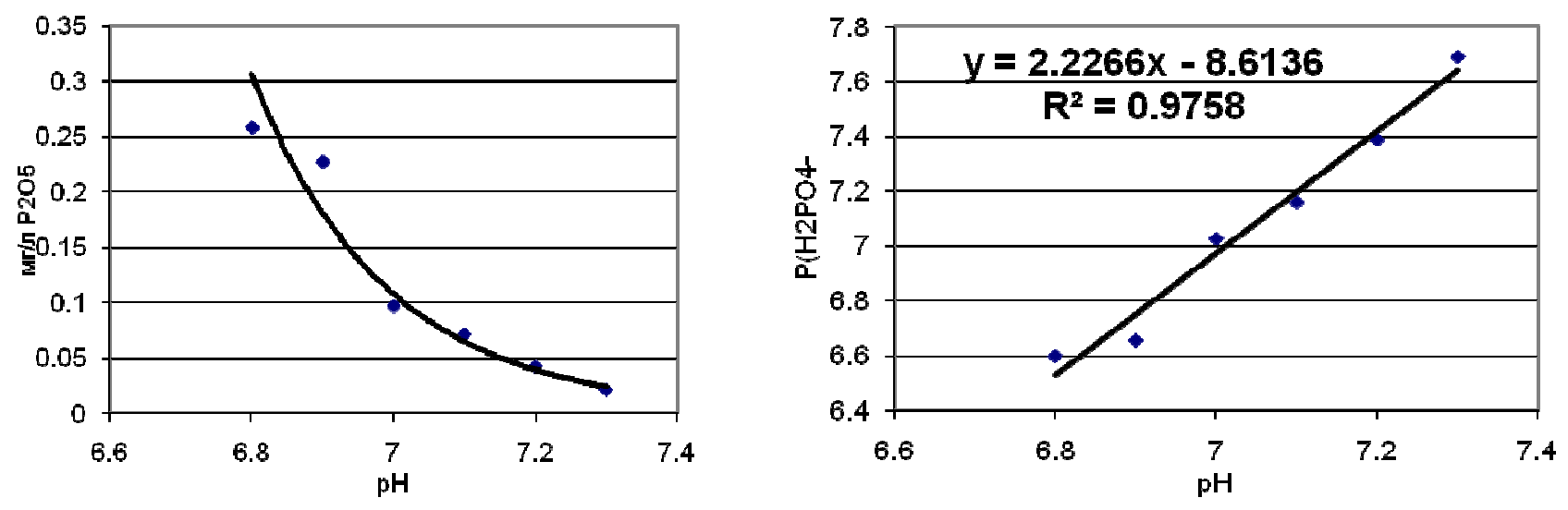

(a) (б)

Рис. 3. Концентраційні залежності вмісту фосфатів у иарі трунту 50-70 см у рівноважному грунтовому розчині чорноземів звичайних на ріллі:

$a$-залежність вмісту $\mathrm{P}_{2} \mathrm{O}_{5}$ від значень $\mathrm{pH}$;

б - залежність значень $\mathrm{pH}_{2} \mathrm{PO}_{4}$ відповідних витяжок від $\mathrm{pH}$.
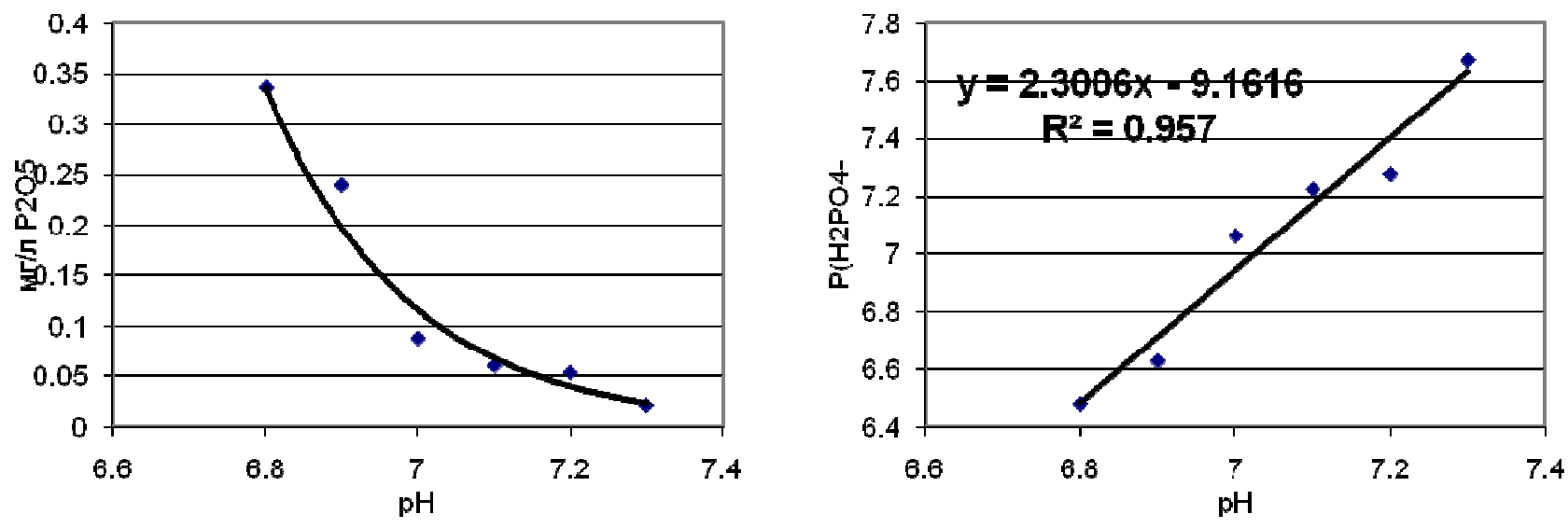

(a) (б)

Рис 4. Концентраційні залежності вмісту фосфатів у рівноважному трунтовому розчині в иарі трунту 50-70 см чорноземів звичайних на цілині:

$a$ - залежність вмісту $\mathrm{P}_{2} \mathrm{O}_{5}$ від значень $\mathrm{pH}$;

б - залежність значень $\mathrm{pH}_{2} \mathrm{PO}_{4}$ відповідних витяжок від $\mathrm{pH}$.

Точна інформація про трофічний стан грунтів, перш за все щодо макроелементів живлення рослин та динаміку їх родючості дає змогу без істотних додаткових витрат більш ефективно використовувати добрива, підвищувати врожаї сільськогосподарських культур і якість одержуваної продукції.

\section{Висновки:}

1. Чорноземи звичайні на лесових породах важкого гранулометричного складу Північного Степу України містять підвищену кількість апатитоподібних сполук. Внаслідок цього використання будь-яких кислотних методів, у тому числі ГОСТ 26204-91 (метод Чирикова) призводить до істотного штучного завищення оцінки фосфатного стану грунтів (на 40-80 мг $\mathrm{P}_{2} \mathrm{O}_{5} /$ кг грунту).

2. Для діагностики фосфатного стану даних грунтів, згідно з вимогами нормативних докуме- 


\section{СІЛЬСЬКЕ ГОСПОДАРСТВО. РОСЛИННИЦТВО}

нтів України, слід використовувати наступні стандарти: ДСТУ 4114 (метод Мачігина), ДСТУ 4727 (метод Карпінського-Зам'ятіної) і ДСТУ ISO 11263 (метод Olsen).

3. Реальна природна забезпеченість орного шару чорноземів звичайних фосфором відповідає межі низької і середньої забезпеченості цим елементом живлення рослин, що підтверджується відомими емпіричними даними про високу ефективність фосфорних добрив на цих грунтах.

4. Підвищеною або високою забезпеченістю фосфором характеризується лише орний шар грунтів, що містить залишкові фосфати добрив, а також верхній гумусовий горизонт цілинних грунтів. Тому для отримання високих урожаїв із високою якістю на чорноземах звичайних Північного Степу України необхідно вносити не менше фосфорних добрив, ніж на інших грунтах країни виходячи з даних грунтової діагностики.

5. Рівноважна концентрація розчинних фосфатів у грунтовому розчині шару $0-30 \mathrm{~cm}$ довгоораних чорноземів формується переважно за ра-

\section{БІБЛІОГРАФІЯ}

1. Якість грунту. Визначення рухомих сполук фосфору за методом Карпінського-Зам'ятіної в модифікації ННЦ ІГА ім. О. Н. Соколовського : ДСТУ 4727-2007. - К. : Держспоживстандарт України, 2008. - 10 с. - (Національний стандарт України).

2. Грунти. Визначення рухомих сполук фосфору і калію за модифікованим методом Чирикова : ДСТУ 4115-2002. - К. : Національний стандарт України, 2002. - 5 с.

3. Эффективность использования фосфорных удобрений в агроценозах зерновых культур / [Крамарев С. М., Красненков С. В., Токмакова Л. Н. и др.] : матеріали міжнар. наук.-практ. конф. [«Наукові доповіді. Фосфор і калій у землеробстві. Проблеми мікробіологічної мобілізації»]. Чернігів : КП «Друкарня». №13. - 2004. - С. 56-65.

4. Медведєв B. В. Проблема фосфору в Україні та шляхи іiі розв'язання / В. В. Медведєв // Bicник аграрної науки. - 2000. - №7. - С. 82-84.

5. Металіді B. C. Сировинна база фосфатів України / В. С. Металіді, І. В. Щепель // Мінеральні ресурси України. - 1999. - №2. - С. 267-269.

6. Носко Б. С. Фосфатний режим грунтів i ефективність добрив / Б. С. Носко. - К. : Урожай, 1990. - 153 с.

7. Післядія добрив на фосфатний режим чорноземів України / [Носко Б. С., Бабинін В. І., Бурлакова Л. М. та ін.] // Вісник аграрної науки. 2008. - №12. - C. 17-22.

8. Носко Б. С. Влияние состава и свойств почв хунок дикальційфосфату $\mathrm{CaHPO}_{4}$, що пов'язано з залишками фосфорних добрив, тобто монокальційфосфат $\mathrm{Ca}\left(\mathrm{H}_{2} \mathrm{PO}_{4}\right)_{2}$, який первинно потрапляє у грунт, з часом переходить до менш розчинної форми дикальційфосфату, але розчинність цієї сполуки більш висока у порівнянні 3 іншими сполуками кальцію з ортофосфорною кислотою, окрім монокальційфосфату.

6. Рівноважна концентрація розчинних фосфатів у грунтовому розчині шару $0-30$ см цілинних чорноземів формується переважно за рахунок октокальційфосфату - також досить розчинної сполуки, але менш розчинної за дикальцій фосфат.

7. Формування рівноважного розчину фосфатів у горизонті 50-70 см довгоораних та цілинних чорноземів формується за рахунок гідроксилапатиту $\left[\mathrm{C}_{10}\left(\mathrm{PO}_{4}\right)_{6}(\mathrm{OH})_{2}\right]$. Таким чином, за тривалий час сільськогосподарського використання чорноземів не відбулося значного трансформування основного джерела розчинних фосфатів у підпахотному горизонті.

на результаты определения содержания подвижного фосфора химическими методами / Б. С. Носко, А. А. Христенко // Агрохимия. - 1996. - №4. - C. 87-94.

9. Носко Б. С. Фосфорити як джерело живлення сільськогосподарських культур / Б. С. Носко, А. О. Христенко, В. І. Бабинін // Використання нетрадиційних сировинних ресурсів у сільському господарстві : [3б. наукових статей і доповідей]. - Луцьк : Надстир'я, 1997. - С. 18-20.

10. Носко Б. С. Проблема фосфору в землеробстві України / Б. С. Носко, А. О. Христенко, В. П. Максимова // Вісник аграрної науки. 1999. - №5. - C. 13-16.

11. Христенко А. О. Діагностика вмісту рухомих сполук фосфору в грунтах / А. О. Христенко // Вісник аграрної науки. - 1998. - №4. - С. 21-25.

12. Христенко $A$. A. Проблема изучения фосфатного состояния почв / А. А. Христенко // Агрохимия. - 2001. - №6. - С. 89-95.

13. Христенко A. О. Розробка стандарту України на методи визначення рухомих сполук фосфору і калію в грунтах / А. О. Христенко // Вісник аграрної науки. - 2003. - №6. - С. 9-13.

14. Христенко А. О. Вплив складу і властивостей грунтів на результати визначення вмісту рухомого фосфору за методом Мачигіна / А. О. Христенко, Н. П. Копоть, Л. М. Бурлакова // Агрохімія і грунтознавство. - 2001. - №61. - С. 84-92.

15. Христенко А. О. Оцінка фосфатного стану грунтів на основі Міжнародного стандарту / 
А. О. Христенко, М. Є. Лазебна // Вісник аграрної науки. - 2008. - №10. - С. 16-19.

16. Христенко А. О. Рухомість «рухомих» елементів живлення рослин у грунті // Вісник аграрної науки. - 2009. - №8. - С. 16-20.

17. Перспективні шляхи виробництва фосфорних добрив в Україні / [Щегров Л. М., Антрап- цева Н. М., Кухарь В. П. та ін.] // Вісник аграрної науки. - 2001. - №9. - С. 13-15.

18. Sequential phosphorus extraction of a 32Plabeled Oxisol under contrasting agricultural systems / [Buehler S., Oberson A., RaoI M. et al.] // Soil Sci. Soc. Am. J. - 2002. - V. 66 - P. 868-877 